JEL: F13, F33, F62, Q11, Q17, Q18

\author{
Josef Abrhám ${ }^{1}$, Milan Vošta ${ }^{1}$, Peter Čajka ${ }^{2}$, Filip Rubáček ${ }^{1}$ \\ ${ }^{1}$ Metropolitan University Prague \\ ${ }^{2}$ Matej Bel University \\ ${ }^{1}$ The Czech Republic \\ ${ }^{2}$ The Slovak Republic
}

\title{
THE SPECIFICS OF SELECTED AGRICULTURAL COMMODITIES IN INTERNATIONAL TRADE
}

Purpose. This paper evaluates the involvement of three selected agricultural commodities (rice, coffee and soya) in international trade. The aim is to analyze the specification of foreign trade in selected commodities and assess their different significance between representations in domestic markets and exports. This article will also assess other contexts related to international trade in these three commodities, including the negative effects on their trade. Based on the set goal, a research question was asked which evaluates the different position of the examined agricultural commodities on world export markets in relation to domestic consumption.

Methodology / approach. The theoretical anchoring of the issue under study are the approaches taken to international economic relations with the emphasis on the specific features of agricultural trade. The methodological framework of the present study is based on the systematic analysis of the spatial distribution of production capacities, the territorial analysis of exports and imports within the world agricultural market and qualitative evaluation of the specifics of selected export commodities and their role in the economy of countries, including labour market importance and in the possibilities of their use.

Results. The paper presents the results of the involvement of the rice, coffee and soya in international trade analysis. Most rice production is consumed on domestic markets. Unlike rice, most of the coffee produced is exported and less is consumed within the growing countries themselves. Although domestic coffee consumption is increasing, more than $70 \%$ of world production is exported. Soya bean production has increased significantly over the past 50 years as a result of the rising demand for animal feedstuff and biofuels. Almost three quarters of soya bean production is consumed as feedstuff.

Originality / scientific novelty. The main contribution of the article is in the application level the elaboration of a comparative view of three selected agricultural commodities. At the theoretical level of the study, it represents a contribution to the discussion within the approaches to the organization of global agricultural trade, the interdependence of economic policies of states, trade ties and the impact on labour markets in relation to production. Agricultural commodities remain an important item in world international trade. However, their share in the total volume is gradually declining. They play an important role in the maintenance of individual countries, but at the same time they are of great economic importance, although we can also mention the less positive aspects of their production, including their impact on the environment. At the same time, it is necessary to realize that this sector is essential for human survival and also that agriculture is important from the point of food security for the population, which can contribute to and increase the level of agricultural protectionism (resilience to world market disruptions or uncontrolled import of genetically modified (GM) food and the transmission of animal diseases). Agriculture is one of the most sensitive economic sectors in the world. Nevertheless, agricultural exports have several economic benefits, including stimulating a wide range of agricultural-related industries, transport suppliers, processing and farm inputs. 


\section{Agricultural and Resource Economics: International Scientific E-Journal}

http://are-journal.com

Practical value / implications. The production of agricultural commodities is of great importance to the economies of individual states, where it contributes to the creation of direct, indirect and induced jobs. The agrarian sector is a key sector, especially for less developed countries. The analysis confirmed the high tradability of all commodities examined and is documented by their involvement in the international division of labour in the global projection.

Key words: international trade, export, import, agriculture, rice, soya, coffee.

Introduction and review of literature. As Satterthwaite et al. [1] already point out, urbanization, as a result of the constant growth of the population together with the growing level of income, of course increases the demand for food. Following these aspects, a structural transformation of the global agro-food system must logically have taken place, which is further supported by technological progress and facilitated by economic policies aimed at free trade and an export-based development model. The environmental pressures exerted by food systems have increasingly dominated the research agenda on food security, focusing on agricultural and livestock production practices and related sustainability and welfare considerations [2]. The need for policy interventions to arrive negative trends in the context of transformations in agricultural land both in terms of land use and land-use changes and achieving sustainable development is being addressed by Prabhakar [3] and more. To increase the production of agricultural commodities such as soya beans and corn, and an increased demand for land used for cultivation is led by a growing demand for meat and fuels (e.g. Tiwari et al. [4], Dumortier et al. [5]). This area in the context of food security and build the institutional capacity to respond to unexpected events is further addressed, for example, by Nicholson et al. [6], but also by Adamchick and Perez [7], Nicholson et al. [8], Ickowitz et al. [9] and Stephens et al. [10].

In general, China, India, Brazil and the USA are considered to be the key producers of agricultural commodities in the world. e.g. Willer \& Lernoud [11], Lopez et al. [12] and Schleifer [13]. In terms of key agricultural commodities, we are talking about wheat, corn, rice and soya beans as by far the most important crops in terms of total area (each from 120 to 220 million hectares). In the case of maize and soy beans, their dominant role can be explained by their "multiple and interchangeable uses both for food and feed, but also for fuels and industrial materials", therefore for these commodities, together with sugar cane and oil palm, the concept of "flex crops" is established de los Reyes and Sandwell [14]. However, according to the OECD, the internationally traded share of the most important agricultural products represents only a fraction of their global production, often below $50 \%$. Over the last two decades, these shares have remained constant for key agricultural products, with the exception of soya beans, where it is interesting that the internationally traded share according to Greenville et al. [15] has increased by $20 \%$.

Agriculture is one of the most sensitive economic sectors all over the world. Nevertheless, agricultural exports have several economic benefits. It can help to stimulate a wide array of industries linked to agriculture, including transportation, 
processing, and farm input suppliers. Furthermore, most of the future growth in food demand is expected to occur in developing countries. However, there are some circumstances (increased trade liberalization, population growth, urbanization, changing diets) which cause an intense increasing in international trade in agricultural goods, countries have to face with several challenges as well (such as climate change, deteriorating soil conditions, biological diversity loss). All in all, agriculture is a specific economic sector not only in developing countries but in developed countries as well. It requires a special treatment and, in some cases, also government intervention. While international trade in non-food products mainly carried upward with gradual liberalization and lowering tariffs in recent decades (which is the result of several rounds of international trade negotiations), it was not the case in the trade of agricultural products. Unequal position of agriculture compared to other economic sectors leads to the need for protectionism [16, p. 22].

International trade is currently exposed to a wide range of external and internal factors. The trade in agricultural commodities is no exception in this respect. The identification of the various factors affecting this trade makes it possible to determine the significant market changes. The share of agricultural products as part of the total world export of raw materials is constantly decreasing. At present, it represents only $1.5 \%$ of the value of the world's exports. Nevertheless, the agricultural sector is of key importance for many countries and regions. In absolute terms there are more and more workers being employed in agriculture. The present study offers an analysis of three agricultural commodities, which are distinguished by the specific features of the product 's distribution and involvement in international trade. These commodities have an important nutritional function for the population and are used as an indispensable component of the feed base for animal production [2, 9]. Current research in this area is supported by selected references from international studies (FAO, DW, ICO, ASA) and articles in peer-reviewed journals $[17,18,19,20]$. The aim of this study is to analyse the involvement of the rice, coffee and soya in international trade. We evaluate the territorial structure of trade in these commodities, as well as the positions occupied by the largest exporters and importers. At the same time, we assess the other links related to the international trade in these aforementioned commodities, including the negative effects.

The purpose of the article. This paper evaluates the involvement of three selected agricultural commodities (rice, coffee and soya) in international trade. The aim is to analyse the territorial structure of trade in these commodities and the position of the largest exporters and importers. At the same time, this paper will assess other links related to the international trade of these three named commodities, including any negatives affecting their trade.

Theoretical framework. The theory of concentrated action emphasizes the influence of organized interest groups of farmers who are able to communicate with each other, influence the legislative process and promote economic objectives [19]. The synergy of agricultural entrepreneurs with regional actors and institutions in rural areas can also be observed. The theory of institutional delays cites the slower 
adaptation of agricultural policy to changes in the global economy as one reason for excessive protectionism. Governments and international organizations delay their responses to world price developments, growth of automation, changes in business structure, productivity gains, climate change, changes in the comparative advantages of agricultural areas, etc. markets [21]. The World Trade Organization divides the instruments of agricultural trade regulation into three groups; ranking them according to their levels of severity: Minimum Trade Distorting Aid; Moderate Production Support and the Most Harmful Measures.

In addition to the tendencies towards gradual liberalization, agricultural trade has seen significant shifts in territorial structure and consumer behaviour over the past two decades. The most significant phenomenon was an increase in the share of developing and developing countries in total agricultural trade. Brazil, China, India and Indonesia are among the top ten largest exporters of agricultural commodities worldwide. Russia is among the twenty largest exporters and the top ten importers. The increase in the share of emerging economies in agricultural imports is supported by rising their per capita incomes in order to reduce poverty. Export performance is due to the growth of agricultural productivity. Developed countries are also increasingly involved in world trade. The share of trade among developing countries (the so-called south-south trade) is thus increasing. However, the negative phenomenon in the least developed countries (especially in sub-Saharan Africa) is faster growth of imports than exports, which negatively affects the balance of total agricultural trade of these countries [22].

Methodology. The methodological framework of this study is based on a systematic analysis of the spatial distribution of production capacities as well as the territorial analysis of exports and imports in the global agricultural market. Each of these three commodities under examination is evaluated through a fundamental analysis of the context. This aims to determine the main factors affecting the market. The supply and demand side is defined on the basis of economic-geographical indicators. Statistical data are monitored within the framework of trend analysis based on the historical-logical method of cognition. On the basis of analyticalsynthetic procedures, conclusions are drawn from the development trends in the international agricultural trade. These show the character of the markets for the agricultural commodities in question.

Data used in this study was collected from the Statista, FAO, ICO and USDA dates. Top 3 commodities considered during our study period were, specifically rice, coffee and soya, which are distinguished by the specific features of the products distribution and involvement in international trade. These commodities have an important nutritional function for the population and are used as an indispensable component of the feed base for animal production. We analyse the period of 5 years which ranges from 2013 to 2018. To understand the depth knowledge of involvement of three selected agricultural commodities in international trade, more past data has to be considered.

With regard to the used methods, the study focuses on the qualitative side of 


\section{Agricultural and Resource Economics: International Scientific E-Journal http://are-journal.com}

research and the logical context of selected agricultural commodities that do not require more detailed empirical research. We will use the quantitative research method only to verify if the import or export of the examined commodity differs significantly in studied years. For this purpose, we use a one-way Analysis of Variance (ANOVA) with the following hypothesis [23]:

$$
\begin{gathered}
H_{0}: \quad \mu_{1}=\mu_{2}=\mu_{3} \quad\left(\text { for Rice } \mu_{1}=\mu_{2}=\mu_{3}=\mu_{4}\right) \\
H_{1}: \quad \text { Not all averages are the same. }
\end{gathered}
$$

We use this formula for the one-way ANOVA F-test statistic with degrees of freedom $\mathrm{m}-1, \mathrm{n}-\mathrm{m}$ :

$$
F=\frac{M S_{A}}{M S_{E}} \text {, where } M S_{A}=\frac{\sum_{j} n_{j}\left(\bar{x}_{j}-\bar{x}\right)^{2}}{m-1} \text { and } M S_{E}=\frac{\sum_{j} \sum_{i}\left(x_{i j}-\bar{x}_{j}\right)^{2}}{n-m}
$$

The theoretical anchoring of the issues under examination are the approaches taken to international economic relations with a focus on the specific features of agricultural trade. The origins of foreign trade theories are associated with the influence of Mercantilists who supported economic protectionism. Later classical theories have shown the positive effects of international trade on the wealth of all participants [24]. Theories based on comparative advantages presuppose interindustry trade with final products, which is characterized by the exchange of different types of products. In recent decades, the commodity structure of world trade has shown a strong increase in the share of intra-industry trade. This means the export and import of the same groups of goods (similar commodities). Currently, intermediates make up the majority of tradable goods. The expansion of global production chains affects the growth of vertical specialization, international outsourcing and offshoring services. Organizational schemes for changing business relations are in place [25].

Results and discussion. At present, agricultural products are less and less a part of world exports of goods. In 2018, agricultural raw materials exports amounted to approximately $1.5 \%$ of world export value. For example, in 1965, agriculture accounted for almost 10 percent of world exports [26]. From the point of view of countries' involvement in agricultural trade, the distribution of agricultural production in those areas with specific and different social and natural conditions is still vital. This results in considerable regional differentiation in the quality, volume and countries' engagement in international trade.

The following analysis takes a look at three selected commodities - rice, coffee and soya, which are characterized by the specific features of product distribution and involvement in international trade. They play an important role in the maintenance of the individual countries, but at the same time they are of great economic importance, and we can mention the less positive aspects of their production, including their environmental impact.

Rice as one of the basic food staples also plays a significant role in the world's agricultural trade. Rice prices rose more than $100 \%$ in 12 months in real terms [27]. A typical feature of the relationship between rice production and export is that the 


\section{Agricultural and Resource Economics: International Scientific E-Journal}

http://are-journal.com

largest rice producers consume most of their production on their domestic markets and export only a minor part of their production. It is reported that only 7 percent of the world's total rice is traded. Thus, a strong specialization in rice production in some developing countries undoubtedly affects not only the trade balance of these countries, but also shapes their labour markets as well as the height of their Gross Domestic Product. It can be said, too, that in addition to the food function, rice also fulfils an important economic function. Nearly a billion people are dependent on rice cultivation and processing in terms of income and employment. In 2017, the world produced nearly 770 million metric tons of paddy rice. Asian countries traditionally have the largest share of world rice production. According to the latest official figures, in 2017, with a production volume of over 210 million tons, China was the world's leading producer of paddy rice, followed by India and Indonesia. Monsoon Asia maintains a dominant position in rice production ( $90 \%$ of the harvest). The largest producer regions are the Sino-Japanese (nearly $40 \%$ of world production), South Asia (30 \%), Southeast Asia (25\%), and to a lesser extent the African (4.8\%) and the Americas regions (4.6\%), where rice is grown mainly in Brazil and the USA. These are increasingly affected by the situation on world markets thanks to modern methods of cultivation in the lowlands of the Gulf of Mexico [22].

It should be noted that the largest rice producers are also the most populous countries in the world, which are also the largest consumers. China, India and Indonesia, as the three largest rice producers, are also the largest consumers, and the link between the population and local production is essential.

Rice is an important element of international trade. It is one of the ten most traded foodstuffs and agricultural commodities. The rice trade is also characterized by some instability and uncertainty. The international rice market is also relatively narrow in terms of participating countries as well as of unequally represented countries. It also takes advantage of the various protectionist measures that exist. States seek to protect their internal markets; which are crucial for them; from external influences. The stabilization policies of these states contribute to the international volatility of rice prices. Compared to other cereals, the volume of rice being traded is still considerably smaller and has never achieved significant growth.

The largest rice exporters in 2018 were India; which exported 12.3 million tons of rice; roughly a quarter of the world's exports. The second most important exporter was Thailand (10.3 million tons $-21.6 \%)$ and the third most important country in rice exports was Vietnam; which generated about $15 \%$ of world rice exports [28]. In the long term, Thailand's position as the largest rice exporter has been taken by India. In 2012, Thai rice exports declined by more than $30 \%$ due to controversial measures taken by the Thai government, which increased feed-in tariffs, and in turn led to Thailand's competitiveness on world markets. Other world exporters include Pakistan, USA, China, Cambodia, Brazil and Uruguay. The largest rice importer is China, which replaced Nigeria in 2013. In 2018, China imported 5.9 million tons of rice (12.4\% of world imports), followed by Nigeria with 2.9 million tons with third and fourth positions taken by Bangladesh and the Philippines, each importing 1.8 and 1.4 million 
tons, respectively. Other major rice importers are Bangladesh, Ivory Coast, Iran, Iraq, Saudi Arabia, Senegal. The EU Member States imported a total of 2 million tons, representing $4.2 \%$ of world rice imports [22]. In recent years, significant changes in China's market behaviour have been observed. Its volumes of imported rice have increased, and the values of rice produced may be deliberately overestimated. The fact is the shrinking area of land suitable for cultivation, especially in the southern regions of China, due to advancing industrialization and urbanization. China concentrates on imports from geographically close countries such as Thailand, Cambodia and Vietnam. The contamination of Chinese agricultural land, making up to $10 \%$ of its unsuitable rice production is also listed as a reason for these changes [29].

In 2018, the international rice trade reached 47.6 million tons. The year-on-year decrease was 1 percentage point. In 2017, however, a record volume of trade in this commodity was recorded. The regional outlook assumes that higher international prices and sufficient stocks due to good harvest or large imports in 2017 will dampen import demand in Africa and Latin America, including the Caribbean. However, the decrease in imports in these regions is contrary to the expected trends that Asian imports will increase to their second highest value, because important Asian customers, especially Indonesia and the Philippines, are once again resorting to international purchasing to replenish their stocks. Demand for imports is also expected to remain stable in the US and Europe. Suppliers are expected to have the largest annual reduction in exports, particularly in Thailand, whose competitive advantage could be undermined by stricter obligations and a strong local currency. Such reductions in exports from India are expected as a result of a reduction in demand from its traditional customers. Furthermore, production shortfalls are expected to weaken the exports of Argentina, the USA and Uruguay, while a number of countries are expected to increase their volume of exports (Australia, Brazil, Cambodia, China, Ecuador, Guyana, Myanmar, Pakistan, Paraguay and Vietnam (Table 1) [22].

Table 1

Export and import of rice in 2013-2018 (in millions of tons)

\begin{tabular}{|l|c|c|c|c|l|c|c|c|c|}
\hline Exporter & $\begin{array}{c}2013- \\
2015\end{array}$ & 2016 & 2017 & 2018 & Importer & $\begin{array}{c}2013- \\
2015\end{array}$ & 2016 & 2017 & 2018 \\
\hline India & 11.1 & 10.0 & 12.5 & 11.9 & China & 5.9 & 5.9 & 5.9 & 5.9 \\
\hline Thailand & 9.1 & 9.9 & 11.6 & 9.9 & Nigeria & 2.8 & 2.2 & 2.7 & 2.9 \\
\hline Vietnam & 8.2 & 6.1 & 6.3 & 7.2 & Bangladesh & 0.9 & 0.1 & 2.4 & 1.8 \\
\hline Pakistan & 3.9 & 4.0 & 3.7 & 4.1 & Ivory Coast & 1.3 & 1.4 & 1.6 & 1.5 \\
\hline USA & 3.2 & 3.4 & 3.4 & 3.2 & Philippines & 1.5 & 0.7 & 1.0 & 1.4 \\
\hline Myanmar & 1.5 & 1.4 & 3.1 & 3.2 & Iran & 1.5 & 1.2 & 1.5 & 1.3 \\
\hline Cambodia & 1.2 & 1.2 & 1.5 & 1.7 & Saudi Arabia & 1.4 & 1.2 & 1.1 & 1.2 \\
\hline China & 0.4 & 0.4 & 1.2 & 1.4 & Senegal & 1.3 & 1.1 & 1.6 & 1.2 \\
\hline Brazil & 0.8 & 0.6 & 0.6 & 0.9 & Iraq & 1.1 & 0.9 & 1.0 & 1.1 \\
\hline Uruguay & 0.8 & 0.9 & 1.0 & 0.8 & Malaysia & 1.0 & 0.8 & 0.9 & 1.0 \\
\hline World & 43.6 & 41.5 & 48.1 & 47.6 & World & 43.6 & 41.5 & 48.1 & 47.6 \\
\hline
\end{tabular}

Source: FAO, 2018. 


\section{Agricultural and Resource Economics: International Scientific E-Journal}

http://are-journal.com

According to the results of ANOVA, the differences in exports and imports at the level of significance $\alpha=0.05$ are not significantly different.

Another crop that is heavily involved in world exports of agricultural products; as well as being part of market agriculture in developing countries; is the coffee plant. Coffee production is divided into three main regions: the Americas $(55 \%$ of production), Asia (32\%) and Africa (12\%) [22]. The world's largest coffee producer is Brazil. In 2018 it produced 61444 thousand. $60 \mathrm{~kg}$ sacks of coffee, which represented $36.4 \%$ of the world's production. Vietnam holds second position, with an $18.4 \%$ share of the world's production, while Colombia lags far behind in third position $(8.2 \%)$. Other major producers are Indonesia, Ethiopia, Honduras, India, Uganda, Mexico and Peru [30].

Coffee production has increased in the past year, especially in those countries with the highest production, i.e. Brazil and Vietnam. It is the most important export commodity in Honduras and Ethiopia, and in Vietnam it is the second most important export commodity. World coffee production is expected to decline slightly next year, mainly due to the expected decline in Brazilian production. The expected recovery in Indonesian production and the stability of Vietnam should contribute to the growth in production in Asia (Table 2) [28].

Table 2

Export and import of coffee in 2016-2018 (in thousands of $60 \mathrm{~kg}$ bags)

\begin{tabular}{|l|c|c|c|l|c|c|c|}
\hline Exporter & 2016 & 2017 & 2018 & Importer & 2016 & 2017 & 2018 \\
\hline Brazil & 34269 & 30925 & 35383 & EU & 81455 & 79211 & 83869 \\
\hline Vietnam & 27568 & 22439 & 27866 & USA & 28838 & 29488 & 28918 \\
\hline Columbia & 12831 & 12985 & 12808 & Japan & 8026 & 7647 & 7540 \\
\hline Honduras & 5306 & 7341 & 7144 & Russia & 5233 & 5468 & 5288 \\
\hline India & 6086 & 6542 & 5967 & Switzerland & 2816 & 2904 & 5288 \\
\hline World & 119216 & 116872 & 122739 & World & 127633 & 126065 & 129977 \\
\hline
\end{tabular}

Source: ICO, 2020.

Coffee is an important commodity business. In many developing countries it forms the centre of gravity of their exports. However, it is not the most important commodity in global trade. Nonetheless, it is essential for the employment of the population in a number of developing countries, thanks to its very extensive cultivation and processing chain, which contains specific elements. The main exporters are Brazil, Vietnam and Colombia. For example, only in the case of Brazil, as the largest exporter of coffee, covering almost one third of world coffee exports (28.8\%), according to Samora [27], Arabica coffee prices rose by more than $45 \%$ in 12 months from 2019 to 2020 , even in nominal expression.

Other coffee exporting countries include Honduras, Indonesia, India, Uganda, Peru, Ethiopia and Guatemala. The main geographical feature of foreign trade is the flow of supply from developing countries to developed countries. In comparison with the above-mentioned rice commodity, a larger part of production is exported to individual countries, while a smaller part is consumed in the producing country.

Table 2 shows that coffee imports are dominated by EU countries, the USA and 
Japan. In addition to the above-mentioned EU countries (i.e., Germany, Italy, France), the largest imports go to Belgium, Spain, Great Britain and Russia. The USA, Germany, Italy and France are at the forefront because they are among the global players in world trade. Moreover, in the case of Germany, for example, half of the import volume is re-exported on to other European countries.

Coffee is grown in more than 70 countries and is reported to be a source of subsistence for up to 25 million households. Over $20 \%$ of production is carried out in the world's poorest countries, where a significant proportion of the population is dependent on the cultivation of this commodity. Although domestic coffee consumption is increasing, more than $70 \%$ of world production is exported. Some countries are heavily dependent on exports and are often low-income countries (according to the World Bank classification). Among the low-income countries, coffee exports account for a high proportion of the total exports of the following countries: Burundi (35\%), Ethiopia (25\%), Uganda (15\%), Rwanda (10\%). In Latin America, Honduras (25\%) and Nicaragua (15\%) have the highest export dependency; [31, p. 21]. However, small farmers in underdeveloped countries, in particular, are exposed to great agricultural and market risks. Thus, for many countries, coffee growing is one of the engines of economic and social development. Therefore, it is essential for them to overcome all barriers and to be able to take advantage of increasing global demand. Coffee remains an export commodity, but the traditional dichotomy of producing and importing countries that consume coffee is being increasingly questioned. Over the past two decades, domestic consumption in producer countries has grown faster than consumption in the import markets. As a result, the share of exports in global production has decreased from $76 \%$ to $72 \%$ [32].

According to the results of ANOVA, the differences in exports and imports Coffee at the level of significance $\alpha=0.05$ are not significantly different.

Another analysed crop is soya. This is one of the most important commodities in the trade in the international trade in agricultural products. It is a legume with a high proportion of proteins and oils, which allows a wide range of applications in agriculture, food and industry. Soya bean production has increased significantly over the past 50 years, mainly as a result of the rising demand for animal feed and biofuels. Almost three quarters of soya bean production is consumed as animal feed [20].

Soya is suitable as a feedstuff for the meat breeds of farm animals due to its high nutritional values. The demand for soya as animal feed is logically increasing as meat consumption increases in the developed and developing countries of the world. Soya bean oil is the second most widespread vegetable oil in the world. In the industry, soya is used, among other things, to produce biodiesel. By contrast, the share of foodstuff uses of soya (soya milk, flour, meat, tofu, etc.) in global consumption is quite low (up to $5 \%$ ). An important factor that has also contributed to the expansion of soya bean cultivation is the possibility of its rotation with corn [18].

De los Reyes and Sandwell [14] point out that although soy still remains an 
important food in China (its main market), it can be said that, like tofu and soy sauce, soy consumption is gradually shifting from food to feed. The Chinese animal industry, where primarily imported soya beans are used as animal feed, is now becoming its largest source of demand. After 1978, a reform era began in the country, which sought to modernize the diet by increasing meat intake, especially among wealthier townspeople, which, combined with government subsidies, logically led to the expansion of the livestock feed sector. Until the beginning of the 20th century, China was the world's largest soya bean producer. It was gradually replaced by the United States of America, which was the dominant producer and exporter on the world market in the 1960s. Since the 1970s, Brazil and Argentina have become more prominent. In 2018, the United States, Brazil, Argentina, China, India, Paraguay and Canada were the main soya bean producers. But the Americas region is absolutely dominant in terms of global production. The three largest producers (USA, Brazil and Argentina) cover more than $80 \%$ of the world market. In 2018, the largest producer of soya beans was the United States (34\%). This was followed by Brazil (32\%) and Argentina (15\%). For both South American countries, soya is the most important agricultural commodity. In Brazil and Argentina, the soya bean plantation area is larger than that of all other crops combined. In the United States, soya is the second most important crop after corn. China, India, Paraguay and Canada account for between 2 and $4 \%$ of world soya production.

The main exporters and importers of soya beans in 2018 are shown in Table 3 [33]. The largest exporters in the year under review were Brazil (52\% of total world exports) and the United States (33\% of total exports). Brazil is also the world's largest exporter and second largest soya bean producer. Soya is a very important crop for Brazil, as it is used not only as foodstuff and animal feed, but also in the production of biodiesel. Another important benefit is its export performance, which has a generally strong positive impact on the Brazilian economy. The market shares of Argentina, Paraguay and Canada are no longer so significant (around 3-4\%). The trade policy is set differently among the main producers. Brazil and the United States stimulate soya bean exports through state aid. By contrast, Argentina has imposed export taxes on soya beans, which serve as revenue for the public purse, but reduce competitiveness on world markets.

Table 3

Exporters and importers of soya beans in millions of tons

\begin{tabular}{|l|c|c|c|c|c|c|c|}
\hline \multirow{2}{*}{ Exporter } & \multicolumn{3}{|c|}{ Export Volume } & \multirow{2}{*}{ Importer } & \multicolumn{3}{c|}{ Import Volume } \\
\cline { 2 - 5 } \cline { 7 - 8 } & 2016 & 2017 & 2018 & & 2016 & 2017 & 2018 \\
\hline Brazil & 61.0 & 70.5 & 79.5 & China & 93.5 & 97.0 & 103.0 \\
\hline United States & 55.1 & 56.2 & 51.0 & EU & 13.4 & 14.1 & 14.2 \\
\hline Argentina & 9.0 & 6.8 & 6.3 & Mexico & - & - & 5.2 \\
\hline Paraguay & 5.4 & 5.8 & 5.6 & Others & 33.3 & 37.1 & 37.7 \\
\hline Canada & 4.4 & 5.5 & 5.3 & World & - & - & 145.7 \\
\hline Others & 6.2 & 5.8 & 6.6 & & & & \\
\hline World & 141.1 & 150.6 & 154.3 & & & & \\
\hline
\end{tabular}

Source: USDA, 2019. 


\section{Agricultural and Resource Economics: International Scientific E-Journal}

http://are-journal.com

As in the previous cases, the differences in imports and exports based on ANOVA testing at the significance level $\mathrm{a}=0.05$ are not significantly different.

According to de los Reyes and Sandwell [14], the key factors in the growth of the soya bean complex are soy's co-products, soya bean meal (used mainly as livestock feed) and soya bean oil (mainly edible oil). Also, in view of the success of soy as animal feed, new potential uses are also constantly being explored. A frequently discussed issue is the desire to expand the use of genetically modified soy as fish feed by agricultural giants such as Monsanto and Cargill, which raises concerns about its potential effects on the environment and health.

In the context of trade in the commodities under investigation, Brazil cannot be left out as a key player in agricultural commodities. According to Samora [27], the price of specific agricultural commodities, such as soya beans, maize, coffee and rice, reached record levels in 2020, as strong demand and a weak currency drove prices higher in local currency. For example, Brazilian soya bean data, according to the survey, increased by more than $50 \%$ in nominal terms compared to the same period last year, mainly due to a steady increase in oil purchases by China from Brazil. In September 2020, the main Brazilian export product reached 137.76 Brazilian reals per bag weighing $60 \mathrm{~kg}$, which is less than 2 reals less than the historical maximum of 139 Brazilian reals in 2012.

The main importer and trading partner of Brazil and the US on the world market is China which, due to the efficiency and food self-sufficiency of the population, has focused on the production of other types of cereals. China is the fifth largest producer of soya beans, but its consumption is several times higher. The reason is its focus on the raising of farm animals (especially pigs). China accounted for more than $60 \%$ of global imports in 2018. The European Union is the second largest importer, but its share of world trade is lower than that of China. China is followed by Argentina, Mexico, Egypt, Japan and Thailand. International trade in soya beans has been substantially affected in recent years by trade disputes between the US and China. In response to US tariffs and tariff restrictions, China imposed a countervailing measure of $25 \%$ of its original value on soya beans imported from the US. For this reason, there was a year-on-year decline in soya exports from the USA to China. South American producers benefited from this trade war.

Conclusions. Agricultural commodities remain an important item of global international trade. However, their share in the total volume is gradually declining. At the same time, the production of agricultural commodities is of great importance to the economies of individual states, where it contributes to the creation of direct, indirect and induced jobs. The agrarian sector is a key sector, especially for less developed countries. The analysis confirmed the high tradability of all commodities examined and is documented by their involvement in the international division of labour in the global projection. Research has shown other country-specific consequences.

An important global trade commodity is rice, which is characterized not only by its food use. In terms of international trade, rice is characterized by the relationship 
between production and export. Most of the production is consumed in domestic markets. Only a smaller portion of the rice grown is traded internationally. It is reported that only $7 \%$ of world rice production is traded. At the same time, the largest rice-producing countries are the most populous countries in the world (China, India, Indonesia and Bangladesh), which are also the largest consumers.

Coffee is a major trading commodity and is the focus of exports in many developing countries. The main geographical feature of the foreign coffee trade is the prevailing direction of exports from developing countries to developed countries. Unlike rice, most of the production is exported from, while less is consumed in, the producer countries. Although domestic coffee consumption is increasing, more than $70 \%$ of world production is exported. The main producers are also the largest exporters (Brazil, Vietnam, Colombia).

In addition to rice, wheat and corn, soya beans are among the main commodities of international agricultural trade. The growth of its production in recent years was caused mainly by an increase in the demand for animal feedstuffs as well as for biofuel. More than $75 \%$ of soya bean production is used as feedstuff. This increased demand is strongly influenced by the rise in the standard of living of the population. Such phenomenon is associated with changes in eating habits in developing countries, where the absolute growth of the middle-class population plays a crucial role. The main importer on the world soya bean market is China (the share of world imports is about (70 \%), which focuses its production capacity more on cereals.

The main benefit of the presented study was the evaluation of the specifics and differences of selected commercial agricultural commodities. While rice as an export crop primarily fulfils the basic nutritional function of states, including an important position in labour markets, coffee is mainly a commercial crop and thus mainly performs economic function, increases the added value of the economy and is a major player in labour markets due to its extensive production and processing process. Another researched commodity, soya bean is characterized by specific features. In addition to the significant export function, where a typical feature is a strong concentration of exports and imports, another feature is the increasingly diversifying use of this commodity.

Acknowledgment. This paper is the result of Metropolitan University Prague research project no. 87-02 "International Business, Financial Management and Tourism" (2021) based on a grant from the Institutional Fund for the Long-term Strategic Development of Research Organizations.

This paper is the result of Metropolitan University Prague research project no. 87-03 "International Relations and Territorial Studies" (2021) based on a grant from the Institutional Fund for the Long-term Strategic Development of Research Organizations.

\section{References}

1. Satterthwaite, D., McGranahan, G. and Tacoli, C. (2010), Urbanization and its implications for food and farming. Philosophical Transactions of the Royal Society B: Biological Sciences, vol. 365, is. 1554, pp. 2809-2820. 
https://doi.org/10.1098/rstb.2010.0136.

2. Fanzo, J., Covic, N., Dobermann, A., Henson, S., Herrero, M., Pingali, P. and Staal, S. (2020), A research vision for food systems in the 2020s: defying the status quo. Global Food Security, vol.26, 100397. https://doi.org/10.1016/j.gfs.2020.100397.

3. Prabhakar, S. V. R. K. (2021), A succinct review and analysis of drivers and impacts of agricultural land transformations in Asia. Land Use Policy, vol. 102, 105238. https://doi.org/10.1016/j.landusepol.2020.105238.

4. Tiwari, A. K., Boachie, M. K., Suleman, M. T. and Gupta, R. (2021), Structure dependence between oil and agricultural commodities returns: the role of geopolitical risks. Energy, vol. 219, https://doi.org/10.1016/j.energy.2020.119584.

5. Dumortier, J., Carriquiry, M. and Elobeid, A. (2021), Where does all the biofuel go? Fuel efficiency gains and its effects on global agricultural production, Energy Policy, vol. 148, 119584. https://doi.org/10.1016/j.enpol.2020.111909.

6. Nicholson, C. F., Stephens, E. C., Jones, A. D., Kopainsky, B., Parsons, D. and Garrett, J. (2021), Food security outcomes in agricultural systems models: current status and recommended improvements. Agricultural Systems, vol. 188, 103028. https://doi.org/10.1016/j.agsy.2020.103028.

7. Adamchick, J. and Perez, A. M. (2020), Choosing awareness over fear: risk analysis and free trade support global food security. Global Food Security, vol. 26, 100445. https://doi.org/10.1016/j.gfs.2020.100445.

8. Nicholson, C. F., Stephens, E. C., Jones, A. D., Kopainsky, B., Parsons, D. and Garrett, J. (2019), Setting priorities to address the research gaps between agricultural systems analysis and food security outcomes in low- and middle-income countries. CCAFS Working Paper no. 255. Wageningen, the Netherlands: CGIAR Research Program on Climate Change, Agriculture and Food Security (CCAFS), available online at: https://cgspace.cgiar.org/handle/10568/99439.

9. Ickowitz, A., Powell, B., Rowland, D., Jones, A. and Sunderland, T. (2019), Agricultural intensification, dietary diversity, and markets in the global food security narrative. Global Food Security, vol.20, pp.9-16. https://doi.org/10.1016/j.gfs.2018.11.002.

10. Stephens, E., Jones, A. D. and Parsons, D. (2018), Agricultural systems research and global food security in the 21st century: an overview and roadmap for future opportunities. Agricultural Systems, vol.163, pp.1-6. https://doi.org/10.1016/j.agsy.2017.01.011.

11. Willer, H. and Lernoud, J. eds (2019), The world of organic agriculture. Statistics and emerging trends 2019. Research Institute of Organic Agriculture FiBL and IFOAM Organics International. Nürnberg, Germany.

12. Lopez, R. A., He, X. and De Falcis, E. (2017), What drives China's new agricultural subsidies? World Development, vol. 93, pp. 279-292. https://doi.org/10.1016/j.worlddev.2016.12.015.

13. Schleifer, P. (2017), Private regulation and global economic change: the drivers of sustainable agriculture in Brazil. Governance, vol. 30, is. 4, pp. 687-703. 
https://doi.org/10.1111/gove.12267.

14. de los Reyes, J. and Sandwell, K. (2018), Flex crops: a primer. Transnational Institute (TNI) Agrarian and Environmental Justice Program. Think piece series on flex crops \& commodities, No. 6 April 2018.

15. Greenville, J., Kawasaki, K. and Beaujeu, R. (2017), How policies shape global food and agriculture value chains. OECD Food, Agriculture and Fisheries Papers, No. 100, OECD Publishing, Paris. https://doi.org/10.1787/aaf0763a-en.

16. Gombkötö, N. (2017), International trade in agricultural and food products. IRACST - International Journal of Commerce, Business and Management, vol. 6, no. 3, pp. 22-28.

17. Sentelhas, P., Battisti, R., Camara, G., Farias, J., Hampf, A. and Nendel, C. (2015), The soya bean yield gap in Brazil - magnitude, causes and possible solutions for sustainable production. The Journal of Agricultural Science, vol. 153, is. 8, pp. 1394-1411. https://doi.org/10.1017/S0021859615000313.

18. Rekow, L. (2019), Socio-ecological implications of soy in the Brazilian Cerrado. Challenges in Sustainability, vol. 7, is. 1, pp.7-29. https://doi.org/10.12924/cis2019.07010007.

19. Svatoš, M. and Smutka, L. (2012), Development of agricultural trade and competitiveness of the commodity structures of individual countries of the Visegrad Group. Agricultural Economics - Czech, vol. 58, pp. 222-238. https://doi.org/10.17221/51/2011-AGRICECON.

20. Torrion, J., Setiyono, T. D., Cassman, K. and Specht, J. (2011), Soya bean phenology simulation in North-Central United States. Agronomy Journal, vol. 103, is. 6, pp. 1661-1667. https://doi.org/10.2134/agronj2011.0141.

21. Svatoš, M. and Smutka, L. (2009), Influence of the EU enlargement on the agrarian foreign trade development in member states. Agricultural Economics Czech, vol. 55, pp. 233-249. https://doi.org/10.17221/34/2009-AGRICECON.

22. FAO (2018), Rice Market Monitor, available at: http://www.fao.org/economic/est/publications/rice-publications/rice-market-monitor$\mathrm{rmm} / \mathrm{en}$.

23. Hendl, J. (2004), Přehled statistických dat: analýza a metanalýza dat. Portál, Praha, Czech Republic.

24. Krugman, P. R. and Obstfeld, M. (2003), International Economics: theory and Policy, 6th ed, Addison Wesley, USA.

25. Rojíček, M. (2012), Impact of Globalisation on the Functioning of International Trade. Politická ekonomie, vol. 2, pp. 187-207. https://doi.org/10.18267/j.polek.837.

26. World Bank (2020), The World Bank Factbook, available at: https://www.cia.gov/library/publications/the-world-factbook/fields/219.html.

27. Samora, R. (2020), From soy to coffee, brazil ag commodities rise to record prices. Reuters, available at: https://www.agriculture.com/markets/newswire/fromsoy-to-coffee-brazil-ag-commodities-rise-to-record-prices.

28. Statista (2020), Principal rice exporting countries worldwide in 2018/2019, 
available at: https://www.statista.com/statistics/255947/top-rice-exporting-countriesworldwide-2011.

29. Ewing, J. J. and Hongzhou, Z. (2013), China as the world's largest rice importer: regional implications, available at: https://reliefweb.int/report/china/chinaworld\%E2\%80\%99s-largest-rice-importer-regional-implications.

30. ICO (2020), Find out more in the ICO's latest coffee market report, available at: http://www.ico.org/new_historical.asp.

31. ICO (2019), Coffee development report, available at: http://www.ico.org/documents/cy2018-19/ed-2318e-overview-flagship-report.pdf.

32. FAO (2020), Food and Agriculture Data, available at: http://www.fao.org/faostat/en/\#data/QC/visualize.

33. USDA (2019), USDA foreign agricultural service, available at: https://www.fas.usda.gov/commodities/soya beans.

\section{Citation:}

Стиль - ДСТУ:

Abrhám J., Vošta M., Čajka P., Rubáček F. The specifics of selected agricultural commodities in international trade. Agricultural and Resource Economics. 2021. Vol. 7. No. 2. Pp. 5-19. https://doi.org/10.51599/are.2021.07.02.01.

Style-APA:

Abrhám, J., Vošta, M., Čajka, P. and Rubáček, F. (2021), The specifics of selected agricultural commodities in international trade. Agricultural and Resource Economics, vol. 7, no. 2, pp. 5-19. https://doi.org/10.51599/are.2021.07.02.01. 